\title{
Antidiabetic and antihyperlipidemic activity of Euphorbia thymifolia L. extracts on streptozotocin-nicotinamide induced type 2 diabetic rats
}

\author{
Ghanshyam R. Parmar ${ }^{1 *}$, Kilambi Pundarikakshudu ${ }^{2}$, R. Balaraman ${ }^{1}$ \\ ${ }^{1}$ Department of Pharmacy, Sumandeep Vidyapeeth, Piparia, Waghodia, Vadodara, Gujarat, India-391760 \\ ${ }^{2}$ Department of Pharmacognosy, L. J. Institute of Pharmacy, Between Sarkhej Circle and Kataria Motors, S. G. Road, Ahmedabad -382210, India.
}

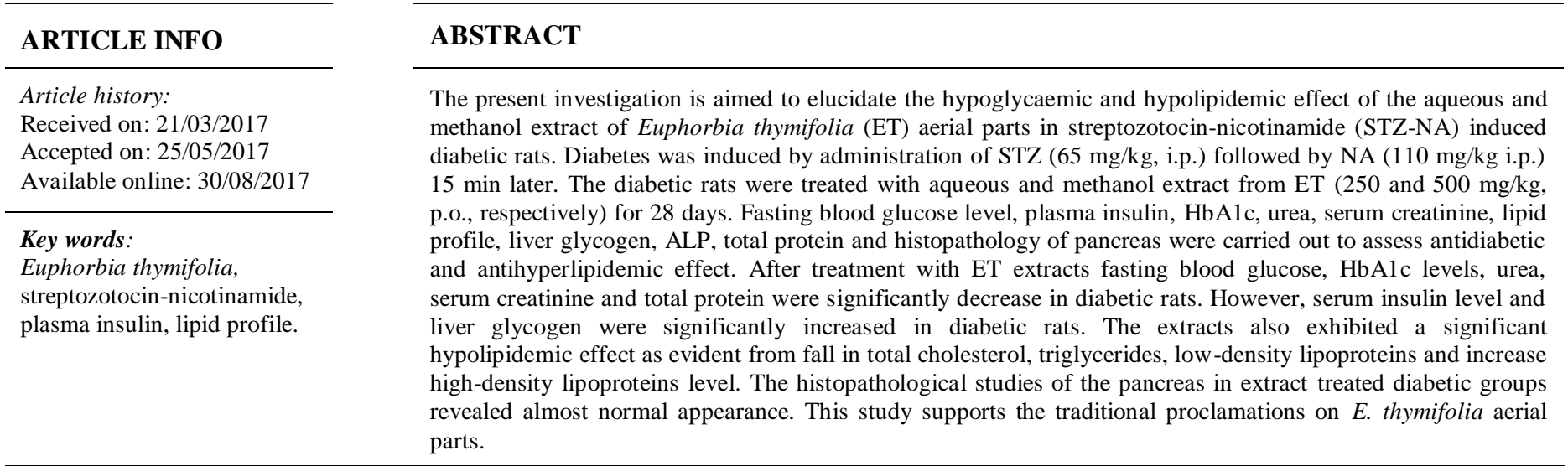

\section{INTRODUCTION}

Type 2 diabetes mellitus (DM) is a chronic metabolic syndrome categorized by increased blood sugar level (hyperglycaemia) consequentially progressive declination in the discharge of insulin, insulin activity or both (Akpan, et al., 2007). The DM is associated with hyperinsulinemia, hyperglycaemia, insulin resistance, hyperlipidemia, and hypertension (Taylor, et al., 1994). The present scenario for the treatment of DM employed regimen, workout, oral hypoglycemic agent and injectable insulin. However, oral antidiabetic drugs and insulin have characteristic adverse effects. This encouraged the quest of novel medicines which may work systematically distinctive way

\footnotetext{
* Corresponding Author

Ghanshyam R Parmar, Department of Pharmacy, Sumandeep

Vidyapeeth, Piparia, Waghodia, Vadodara, Gujarat, India.

Email: ghanstaurus22 @ gmail.com
}

compared to the current drug therapy (Palsamy and Subramanian, 2008). Consequently, research is meant to conventional medicinal plants which are used as a part of practices and also the discovery of new molecules from phytoconstituents with lesser adverse effects (Chandramohan, et al., 2008). Ayurveda, a traditional system of medicine comprises a diverse range from ancient to modern approaches for the treatment and prevention of illness. A traditional Indian system of medicine has represented a few medications from the traditional indigenous plants in the treatment of liver disease, diabetes, inflammation and cardiac disease (Kemper and Lester, 1999).The genus euphorbia is unique in that it contains highly reputed plants useful in various diseases. This genus has diverse chemical entities with a lot of structural variation sources. Such plants like Amla (Embelica officinalis), Bhoiamli (Phyllanthusfractus), Arendmul (Racinuscommunis) etc. are medicinally valuable in the treatment of some chronic disease such as diabetes, liver disease, asthma, inflammation etc., (Mwine and Van Damme, 2011). 
Euphorbia thymifolia (ET) belong to family Euphorbiaceae, known as Nanidudheli, is traditionally used as a blood purifier, sedative haemostatic, bronchial asthma, and inflammation (Lee, et al., 1990). In view of above medicinal properties of Euphorbia thymifolia, it is of interest to undertake a systematic study as their hypoglycaemic activity for such plant. Thus present study was aimed to investigate the antidiabetic and antihyperlipidaemic activities of aqueous and methanol extract of ET aerial part on streptozotocin-nicotinamide induced DM in rats.

\section{MATERIAL AND METHODS Drugs and chemicals}

Glibenclamide (ZydusCadila, Ahmedabad, India) was obtained as gift sample. Streptozotocin (STZ) and nicotinamide (NA) were purchased from Himedia, Mumbai, India. All standard kits were bought from Span Diagnostic lab, Surat, India. All other reagents $s$ and chemical used in the experiment were of analytical grade purchased from SD Fine Chemical, Mumbai, India.

\section{Plant material}

Fresh aerial parts of ET were collected during september 2014 from Amargadh village, Taluka,district of Rajkot, Gujarat, India. The plant was identified and authenticated by CSIRNISCAIR, New Delhi, India. Voucher specimens (DP/SVU/PHCOG/Herb/03) of same have been deposited in SumandeepVidyapeeth University, Vadodara for future reference.

\section{Preparation of extracts}

The collected leaves were subjected to the sun dried, pulverized and sieved through mesh size 40. The cold maceration method was utilized to prepare aqueous and methanol extracts of E. thymifolia (ETW and ETM respectively) for $72 \mathrm{~h}$. The final extract was concentrated using a rotary evaporator (Mack, Ahmedabad) under reduced pressure at a temperature of $60^{\circ} \mathrm{C}$ and subsequently lyophilized and stored in a desiccator and used for further studies. The yield of ETM and ETW extracts was $16.34 \%$ and $6.25 \%(\mathrm{w} / \mathrm{w})$ respectively.

\section{Experimental animals}

Healthy adult male Wistar albino rats (180-200 g, 12-13 week old) obtained from Zydus Research Centre, Gujarat, India, were allow access to water and food ad libitum, and maintained under constant $\left(25 \pm 1^{\circ} \mathrm{C}\right)$, humidity $(65 \pm 10 \%)$ and $12 \mathrm{~h}$ light/dark cycle. The study was sanctioned by CPCSEA and IAEC approved the protocols (Approval No.: SVU/DP/IAEC/2014/03/14).

\section{Acute oral toxicity study}

Healthy overnight starved Wistar rats of either sex weighing 180-200g were utilized to determine acute oral toxicity. The rats were allocated into groups $(n=3)$ and orally fed with methanol and aqueous extracts of ET in ascending doses as 500, 1000, 2500, 3000, 4000 and $5000 \mathrm{mg} / \mathrm{kg}$ body weight (OECD, 2001). They were observed continuously for gross behaviour up to 14 days.

\section{Oral glucose tolerance test (OGTT)}

The overnight starved normal healthy Wistar rats were utilized to perform OGTT (Bonner-Weir, 1988). The rats were allocated into six groups $(n=6)$. Group I to VI administered orally with $0.2 \%$ Carboxymethylcellulose (CMC) solution, aqueous and methanol extracts of EUT $(500 \mathrm{mg} / \mathrm{kg}$ suspended in $0.2 \% \mathrm{CMC}$ ) and standard drug glibenclamide $(5 \mathrm{mg} / \mathrm{kg}$ suspended in $0.2 \%$ CMC), respectively. After treatment with extracts blood samples were withdrawn at $0,30,60$ and $120 \mathrm{~min}$ by retro-orbital puncture under diethyl-ether anaesthesia.The fasting blood glucose (FBG) concentration was measured by diagnostic strips (Accu-check, Roche Diagnosis, USA).

\section{Chemically induced type 2 Diabetes}

The DM was induced in overnight starved normal healthy Wistar rats by administration of STZ $(65 \mathrm{mg} / \mathrm{kg}$, i.p.) followed by NA (110 mg/kg i.p.) $15 \mathrm{~min}$ later (Masiello, et al., 1998). The elevated blood glucose level (hyperglycaemia) was confirmed on the ${ }^{3 \text { rd }}$ and $7^{\text {th }}$ day after administration of STZ-NA, with the help of diagnostic strips (Accu-check, Roche Diagnosis, USA).The rats having FBG level >200 mg/dl along with glycosuria were chosen for the experimental design.

\section{Design of experiment}

The diabetic rats were allocated into seven groups $(n=6)$ as per Table 1. Normal control rats and diabetic control rats received $0.2 \% \mathrm{CMC}$ orally while standard group received glibenclamide (suspended in $0.2 \%$ CMC) orally up to 28 days. The treatment groups were received extracts (suspended in $0.2 \% \mathrm{CMC}$ ) orally up to 28 days orally. All aforementioned treatments were started one week after injection of STZ-NA. All treatments were given daily to the respective group of animals for 28 days.On $28^{\text {th }}$ day blood samples were withdrawn by puncturing the retro-orbital under diethyl-ether anesthesia and stored with or without EDTA tubes. For separation of serum, blood was allowed to clot for 15 min, and it was then centrifuged at $5000 \mathrm{rpm}$ for $20 \mathrm{~min}$. The serum was stored at $-20^{\circ} \mathrm{C}$ until further biochemical analysis.

\section{Biochemical parameters}

The fasting plasma glucose level was estimated by diagnostic strips (Accu-check, Roche Diagnosis, USA). Glycosylated hemoglobin (HbA1c) was estimated from whole blood (Ohkawa, et al., 1979). Serum insulin was estimated using available commercial ELISA kit (Andersen, et al., 1993). Liver glycogen was measured from serum (Carroll, et al., 1956). Total protein, serum creatinine, and urea were estimated by available commercial kits (Lowry, et al., 1951, Owen, et al., 1954, Varley, 1954).

Serum alkaline phosphatase (ALP) was measured by the method of King and Armstrong (1934). Reitman and Frankel (1957) were suggested method for estimation of hepatic amino transferase enzymes which includes aspartate amino transferase (AST or SGOT) and alanine aminotransferase (ALT or SGPT). The serum total cholesterol (TC), triglyceride (TG), low density 
lipoproteins (LDL) and high density lipoproteins (HDL) concentrations were determined using commercial kits by enzymatic photocolorimetric methods (Das, et al., 2015)

\section{Histopathological study}

After scarification of rodent, the pancreas was immediately dissected out and washed instantly with saline and impregnate in formalin $(10 \% \mathrm{v} / \mathrm{v})$ solution. Furthermore, the finely cut sections were stained with Haematoxylin and Eosin (H\&E) and monitored in the microscope (Olympus BX10, Tokyo, Japan) for the occurrence of histopathological changes. The histopathological changes were observed blindly in normal and treated animal groups.

\section{Statistical analysis}

All the values are stated as mean \pm SEM. Control group and treatment groups are statistically tested using one-way ANOVA followed by post hoc Bonferroni multiple comparisons in Prism 5, GraphPad Software, Inc. The significance level was set at $\mathrm{P}<0.05$ for all tests.

\section{RESULTS}

\section{Acute oral toxicity studies in rats}

Aqueous and methanol extracts of ET did not show any acute toxicity symptoms i.e. mortality, morbidity, as well as no significance, changes observed in the general behaviour of animals, up to the dose of 2500 to $5000 \mathrm{mg} / \mathrm{kg}$. Therefore, $1 / 10^{\text {th }}$ dose of extracts was selected as a therapeutic dose for the present study.

\section{The effects of ET extracts on OGTT}

The tolerant elevation in postprandial blood glucose level was observed within $30 \mathrm{~min}$ of administration of oral glucose,

which was maximum at $60 \mathrm{~min}$ in all rats. The treatment with ETM $500 \mathrm{mg} / \mathrm{kg}$ and ETW $500 \mathrm{mg} / \mathrm{kg}$ showed significant $(P<$ $0.01)$ reduction in the blood glucose level in diabetic rats while ETM and ETW $250 \mathrm{mg} / \mathrm{kg}$ showed moderate reduction in blood glucose level (Fig.1).

\section{The effects of ET extracts on the fasting blood sugar level in diabetic rats.}

The FBG of the normal and experimental animals was estimated before and at days $0,7,14,21$ and 28 from treatment. In normal control rats, FBG level was practically similar throughout the study. On contrary, the STZ-NA induced diabetic rats demonstrated a significant increment in the level of FBG as compared to normal control rats. The diabetic rats treated with ET extracts at a dose of $250 \mathrm{mg} / \mathrm{kg}$ and $500 \mathrm{mg} / \mathrm{kg}$ showed a significant $(\mathrm{P}<0.05)$ decrease in the FBG level (Table 1).

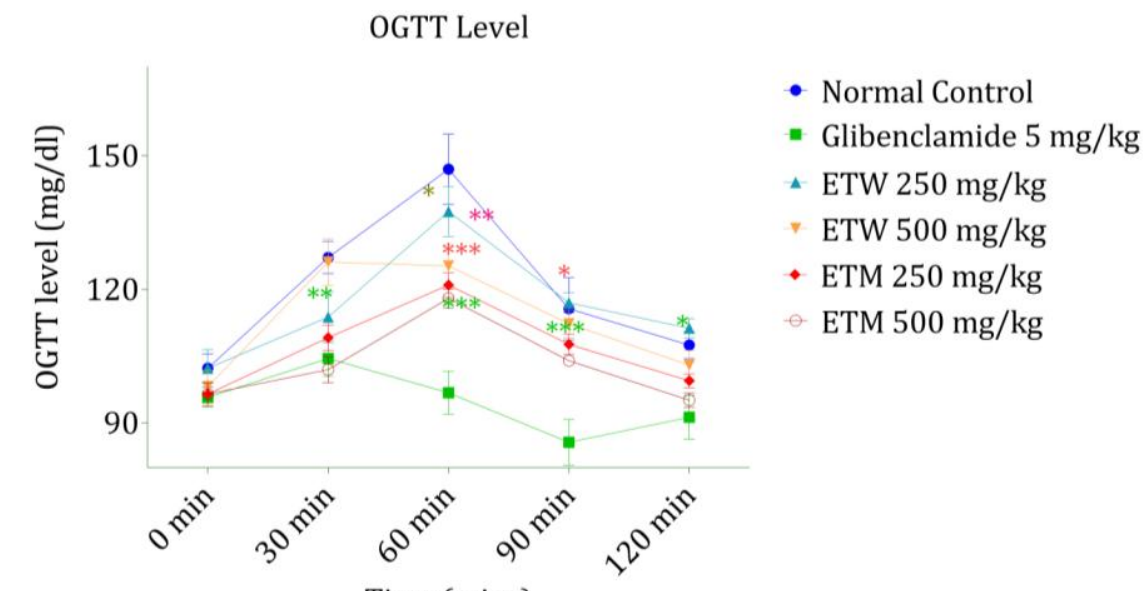

Fig. 1: The effect of ET extracts on OGTT level in rats. All Values are expressed as mean $\pm S E M(n=6)$

$\# \#$ p 0.05 vs. Normal, ${ }^{*} \mathrm{p}<0.05$ vs. Diabetic and ${ }^{* *} \mathrm{p}<0.01$ vs. Diabetic (One-way ANOVA followed by Bonferroni post hoc test).

Table 1: Effect of ET extracts on FBG of diabetic rats.

\begin{tabular}{|c|c|c|c|c|c|}
\hline \multirow[t]{2}{*}{ Groups } & \multicolumn{5}{|c|}{ FBG (mg/dL) } \\
\hline & O Day & $7^{\text {th }}$ Day & $14^{\text {th }}$ Day & $21^{\text {st }}$ Day & $28^{\text {th }}$ Day \\
\hline Normal & $96.33 \pm 1.116$ & $96.66 \pm 1.626$ & $95.33 \pm 1.667$ & $99.00 \pm 2.757$ & $95.667 \pm 1.054$ \\
\hline Diabetic & $270.33 \pm 22.630$ & $293.16 \pm 17.960$ & $302.50 \pm 15.115$ & $306.16 \pm 14.934$ & $341.50 \pm 15.050^{* * *}$ \\
\hline Glibenclamide $5 \mathrm{mg} / \mathrm{kg}$ & $257.50 \pm 16.329$ & $240.50 \pm 13.099$ & $165.833 \pm 4.902$ & $169.667 \pm 4.104$ & $136.667 \pm 2.917^{\mathrm{c}}$ \\
\hline ETW $250 \mathrm{mg} / \mathrm{kg}$ & $269.33 \pm 6.936$ & $230.50 \pm 8.160$ & $196.50 \pm 4.395$ & $175.66 \pm 4.447$ & $156.00 \pm 2.082^{b}$ \\
\hline ETW $500 \mathrm{mg} / \mathrm{kg}$ & $247.83 \pm 14.925$ & $212.66 \pm 9.982$ & $184.83 \pm 4.881$ & $169.00 \pm 3.327$ & $149.66 \pm 1.585^{\mathrm{b}}$ \\
\hline ETM $250 \mathrm{mg} / \mathrm{kg}$ & $251.83 \pm 11.140$ & $217.50 \pm 8.539$ & $191.50 \pm 4.822$ & $177.83 \pm 3.525$ & $162.167 \pm 2.040^{\mathrm{b}}$ \\
\hline ETM $500 \mathrm{mg} / \mathrm{kg}$ & $235.66 \pm 11.896$ & $208.83 \pm 9.680$ & $188.00 \pm 5.663$ & $168.16 \pm 3.953$ & $152.16 \pm 2.455^{\mathrm{c}}$ \\
\hline
\end{tabular}

Values expressed as mean \pm SEM $(\mathrm{n}=6), * * * p<0.05$ vs. Normal, ${ }^{a} p<0.05$ vs. Diabetic, ${ }^{b} p<0.01$ vs. Diabetic and ${ }^{c} p<0.001$ vs. Diabetic. 
Table 2: Effect of ET extracts on biochemical parameters in STZ-NA induced type 2 diabetic rats.

\begin{tabular}{|c|c|c|c|c|c|c|c|}
\hline Parameters & Normal $^{\mathrm{a}}$ & Diabetic $^{\mathrm{a}}$ & $\begin{array}{c}\text { Glibenclamide }^{\mathrm{a}} \\
5 \mathrm{mg} / \mathrm{kg}\end{array}$ & $\begin{array}{c}\text { ETW }^{\text {a }} 250 \\
\mathrm{mg} / \mathrm{kg}\end{array}$ & $\begin{array}{c}\text { ETW }^{\text {a }} 500 \\
\mathrm{mg} / \mathrm{kg}\end{array}$ & $\begin{array}{c}\text { ETM }^{\text {a }} 250 \\
\mathrm{mg} / \mathrm{kg}\end{array}$ & $\begin{array}{c}\text { ETM }^{\text {a }} 500 \\
\mathrm{mg} / \mathrm{kg}\end{array}$ \\
\hline Plasma Insulin $(\mu \mathrm{U} / \mathrm{L})$ & $17.67 \pm 1.256$ & $2.52 \pm 0.388^{* * * *}$ & $8.013 \pm 0.539^{c}$ & $10.23 \pm 0.451^{\mathrm{c}}$ & $10.60 \pm 0.513^{\mathrm{c}}$ & $11.83 \pm 0.477^{\mathrm{c}}$ & $11.70 \pm 0.737^{\mathrm{c}}$ \\
\hline $\mathrm{HbA} 1 \mathrm{c}(\%)$ & $5.33 \pm 0.291$ & $11.95 \pm 0.468^{* * *}$ & $6.90 \pm 0.342^{\mathrm{c}}$ & $9.71 \pm 0.253^{\mathrm{c}}$ & $8.97 \pm 0.306^{\mathrm{c}}$ & $9.078 \pm 0.431^{\mathrm{b}}$ & $7.71 \pm 0.482^{\mathrm{c}}$ \\
\hline Serum Creatinine (mg /dl) & $0.66 \pm 0.046$ & $2.26 \pm 0.143^{* * *}$ & $0.68 \pm 0.054^{\mathrm{c}}$ & $1.82 \pm 0.065^{\mathrm{b}}$ & $1.532 \pm 0.077^{\mathrm{b}}$ & $1.698 \pm 0.034^{\mathrm{b}}$ & $0.736 \pm 0.071^{\mathrm{c}}$ \\
\hline $\operatorname{Urea}(\mathrm{mg} / \mathrm{dL})$ & $39.15 \pm 1.290$ & $105.9 \pm 6.217^{* * *}$ & $39.87 \pm 1.226^{\mathrm{c}}$ & $80.69 \pm 2.690^{\mathrm{b}}$ & $64.19 \pm 1.890^{\mathrm{b}}$ & $83.95 \pm 2.327^{\mathrm{b}}$ & $55.93 \pm 3.102^{\mathrm{c}}$ \\
\hline
\end{tabular}

Values expressed as ${ }^{a}$ mean \pm SEM $(\mathrm{n}=6), * * * p<0.05$ vs. Normal, ${ }^{a} p<0.05$ vs. Diabetic, ${ }^{b} p<0.01$ vs. Diabetic and ${ }^{c} p<0.001$ vs. Diabetic.

Table 3: Effect of ET extracts on liver functions in STZ-NA induced type 2 diabetic rats.

\begin{tabular}{|c|c|c|c|c|c|c|c|}
\hline Parameters & Normal $^{\mathrm{a}}$ & Diabetic $^{a}$ & $\begin{array}{c}\text { Glibenclamide }^{\mathrm{a}} \\
5 \mathrm{mg} / \mathrm{kg}\end{array}$ & $\begin{array}{c}\text { ETW }^{\text {a }} 250 \\
\text { mg/kg }\end{array}$ & $\begin{array}{c}\text { ETW }^{\text {a }} 500 \\
\text { mg/kg }\end{array}$ & $\begin{array}{c}\text { ETM }^{\text {a }} 250 \\
\text { mg/kg }\end{array}$ & $\begin{array}{c}\text { ETM }^{\text {a }} 500 \\
\text { mg/kg }\end{array}$ \\
\hline Liver Glycogen (mg/g) & $55.66 \pm 2.3$ & $7.86 \pm 1.04^{* * *}$ & $48.33 \pm 4.5^{\mathrm{c}}$ & $14.11 \pm 1.03^{\mathrm{c}}$ & $29.08 \pm 1.06^{\mathrm{c}}$ & $25.18 \pm 0.57^{\mathrm{c}}$ & $45.38 \pm 2.37^{\mathrm{c}}$ \\
\hline Total protein $(\mathrm{g} / \mathrm{dL})$ & $8.42 \pm 0.40$ & $5.03 \pm 0.17^{* * *}$ & $7.96 \pm 0.45^{\mathrm{c}}$ & $6.45 \pm 0.21^{\mathrm{c}}$ & $7.54 \pm 0.10^{\mathrm{c}}$ & $7.05 \pm 0.25^{\mathrm{c}}$ & $7.95 \pm 0.22^{\mathrm{c}}$ \\
\hline SGPT (IU/L) & $43.86 \pm 3.506$ & $151.7 \pm 9.824^{* * *}$ & $64.17 \pm 1.797^{\mathrm{c}}$ & $112.3 \pm 3.558^{\mathrm{c}}$ & $106.5 \pm 3.594^{c}$ & $92.33 \pm 6.500^{c}$ & $73.67 \pm 3.373^{\mathrm{c}}$ \\
\hline SGOT (IU/L) & $43.83 \pm 3.506$ & $156.7 \pm 9.739^{* * *}$ & $58.33 \pm 3.658^{\mathrm{c}}$ & $106.0 \pm 2.428^{\mathrm{c}}$ & $101.0 \pm 2.394^{c}$ & $88.17 \pm 6.047^{\mathrm{c}}$ & $67.67 \pm 4.507^{\mathrm{c}}$ \\
\hline ALP (IU/L) & $28.6 \pm 0.94$ & $59.10 \pm 1.28^{* * * *}$ & $30.98 \pm 1.17^{\mathrm{c}}$ & $55.21 \pm 1.11^{\mathrm{c}}$ & $46.00 \pm 1.44^{\mathrm{c}}$ & $51.47 \pm 1.26^{\mathrm{c}}$ & $38.25 \pm 0.89^{c}$ \\
\hline
\end{tabular}

Table 4: Effect of ET extracts on serum lipid profile in STZ-NA induced type 2 diabetic rats.

\begin{tabular}{|c|c|c|c|c|c|c|c|}
\hline Parameters & Normal $^{\mathrm{a}}$ & Diabetic $^{a}$ & $\begin{array}{l}\text { Glibenclamide }^{\mathrm{a}} \\
5 \mathrm{mg} / \mathrm{kg}\end{array}$ & $\begin{array}{l}\text { ETW } 250 \\
\mathrm{mg} / \mathrm{kg}\end{array}$ & $\begin{array}{l}\mathrm{ETW}^{\mathrm{a}} \mathbf{5 0 0} \\
\mathrm{mg} / \mathrm{kg}\end{array}$ & $\begin{array}{l}\mathrm{ETM}^{\mathrm{a}} 250 \\
\mathrm{mg} / \mathrm{kg}\end{array}$ & $\begin{array}{l}\text { ETM }^{\mathrm{a}} 500 \\
\mathrm{mg} / \mathrm{kg}\end{array}$ \\
\hline$\overline{\mathrm{TC}(\mathrm{mg} / \mathrm{dL})}$ & $76.50 \pm 5.396$ & $167.7 \pm 10.94^{\text {*** }}$ & $72.17 \pm 5.659$ & $129.6 \pm 8.01^{b}$ & $107.5 \pm 4.303^{b}$ & $92.00 \pm 8.145^{\mathrm{c}}$ & $91.00 \pm 10.10^{c}$ \\
\hline $\mathrm{TG}(\mathrm{mg} / \mathrm{dL})$ & $64.33 \pm 4.341$ & $165.0 \pm 8.683^{* * *}$ & $89.00 \pm 4.789$ & $120.6 \pm 3.577^{b}$ & $117.2 \pm 5.636^{\mathrm{b}}$ & $118.5 \pm 15.50^{\mathrm{b}}$ & $87.50 \pm 4.209^{c}$ \\
\hline $\mathrm{HDL}(\mathrm{mg} / \mathrm{dL})$ & $42.50 \pm 2.5$ & $11.00 \pm 1.00^{* * * *}$ & $36.50 \pm 2.500$ & $38.50 \pm 1.088^{b}$ & $39.67 \pm 1.054^{\mathrm{c}}$ & $38.67 \pm 0.954^{\mathrm{b}}$ & $50.67 \pm 1.585^{\mathrm{c}}$ \\
\hline $\mathrm{LDL}(\mathrm{mg} / \mathrm{dL})$ & $23.50 \pm 1.50$ & $72.00 \pm 3.00^{* * * *}$ & $32.50 \pm 2.50$ & $50.67 \pm 1.72^{b}$ & $22.20 \pm 1.465^{\mathrm{c}}$ & $63.67 \pm 1.017^{\mathrm{a}}$ & $42.13 \pm 1.122^{c}$ \\
\hline
\end{tabular}

Values expressed as ${ }^{a}$ mean \pm SEM $(\mathrm{n}=6), * * * p<0.05$ vs. Normal, ${ }^{a} p<0.05$ vs. Diabetic, ${ }^{b} p<0.01$ vs. Diabetic and ${ }^{c} p<0.001$ vs. Diabetic.

\section{The effect of ET extracts on plasma insulin, HbA1c, serum creatinine and urea}

The present data indicated that there was a significant $(P$ $<0.05)$ elevation in the level of glycated hemoglobin (HbA1C) and reduction in the level of hemoglobin $(\mathrm{Hb})$. The treatment with ETW (250 and $500 \mathrm{mg} / \mathrm{kg}$ ), ETM (250 and $500 \mathrm{mg} / \mathrm{kg}$ ), and glibenclamide $(5 \mathrm{mg} / \mathrm{kg})$ showed a significant reduction in the level of HbA1c and significant increase in the level of plasma insulin at dose dependant manner (Table 2). However, treatment with ETM and ETW (500 mg/kg) extracts showed highest reduction of $\% \mathrm{HbA} 1 \mathrm{c}$ in diabetic rats.

There was a significant increase in the levels of serum creatinine and urea in diabetic control rats as compared to normal control rats. The administration of ETW (250 and $500 \mathrm{mg} / \mathrm{kg}$ ), ETM (250 and $500 \mathrm{mg} / \mathrm{kg}$ ) or glibenclamide $(5 \mathrm{mg} / \mathrm{kg})$ showed a significant decrease in the levels of serum creatinine and urea as compared to diabetic control rats (Table 2).Nevertheless, a higher dose $(500 \mathrm{mg} / \mathrm{kg})$ of ETM was showed a significant effect in urea and serum creatinine levels in the diabetic rats.

\section{The effect of ET extracts on liver glycogen, SGOT, SGPT, ALP and total protein}

The levels of liver glycogen, SGOT, SGPT, ALP and total protein in control, diabetic induced and drug treated rats were presented in Table 3.The level of liver glycogen and total protein were significantly $(\mathrm{P}<0.05)$ decreased in STZ-NA induced diabetic rats. The glibenclamide and ET extracts treated rats showed a significant $(P<0.001)$ elevation in the level of liver glycogen total protein when compared with diabetic induced rats. The data also represented that there is an induction in transaminase activity of the liver enzymes as results of administration of STZNA in rats. There is a significant improvement noticed in the levels of SGOT, SGPT and ALP is due to the oral treatment with extracts of ET at a dose of $250 \mathrm{mg} / \mathrm{kg}$ and $500 \mathrm{mg} / \mathrm{kg}$.

The data summarized in table 3 reveal that, all the extracts shows a marked protective effect on these biochemical parameters in treatment groups. However, treatment with ETM $(500 \mathrm{mg} / \mathrm{kg}$ ) shows a marked effect as compared to other extracts in diabetic rats.

\section{The effect of ET extracts on serum lipid profile}

The results in table 4 represented the serum lipid profile includes TC, TG, LDL and HDL levels in STZ-NA induced type 2 diabetes in rats. In diabetic rats, there was a significant $(P<0.05)$ increase in lipid profile except HDL as compared to normal control rats. Treatment with glibanclamide and extracts of ET were shown significant $(P<0.001)$ reduction in TC, TG and LDL level. Similarly, HDL level decrease in STZ-NA induced diabetic rats as compared to normal rats. After the treatment with extracts of ET and glibenclamide to the diabetic rats, HDL level was increased significantly $(P<0.001)$ as compared to diabetic control rats. The data summarized in table 4 reveals that, treatment with ETM (500 $\mathrm{mg} / \mathrm{kg}$ ) shows a marked effect on lipid profile as compared to other extracts in diabetic rats. 


\section{The histopathological study of the pancreas}

Histopathology studies indifferent treated groups showed normal physiology in normal control rats. Treatment with extracts from ET resulted in the refurbishment of pancreatic islets to near normal construction. This suggests a possible influence of extracts of ET to regeneration or repair of the cells of islets of Langerhans in STZ-NA treated group (Fig. 2A-G).

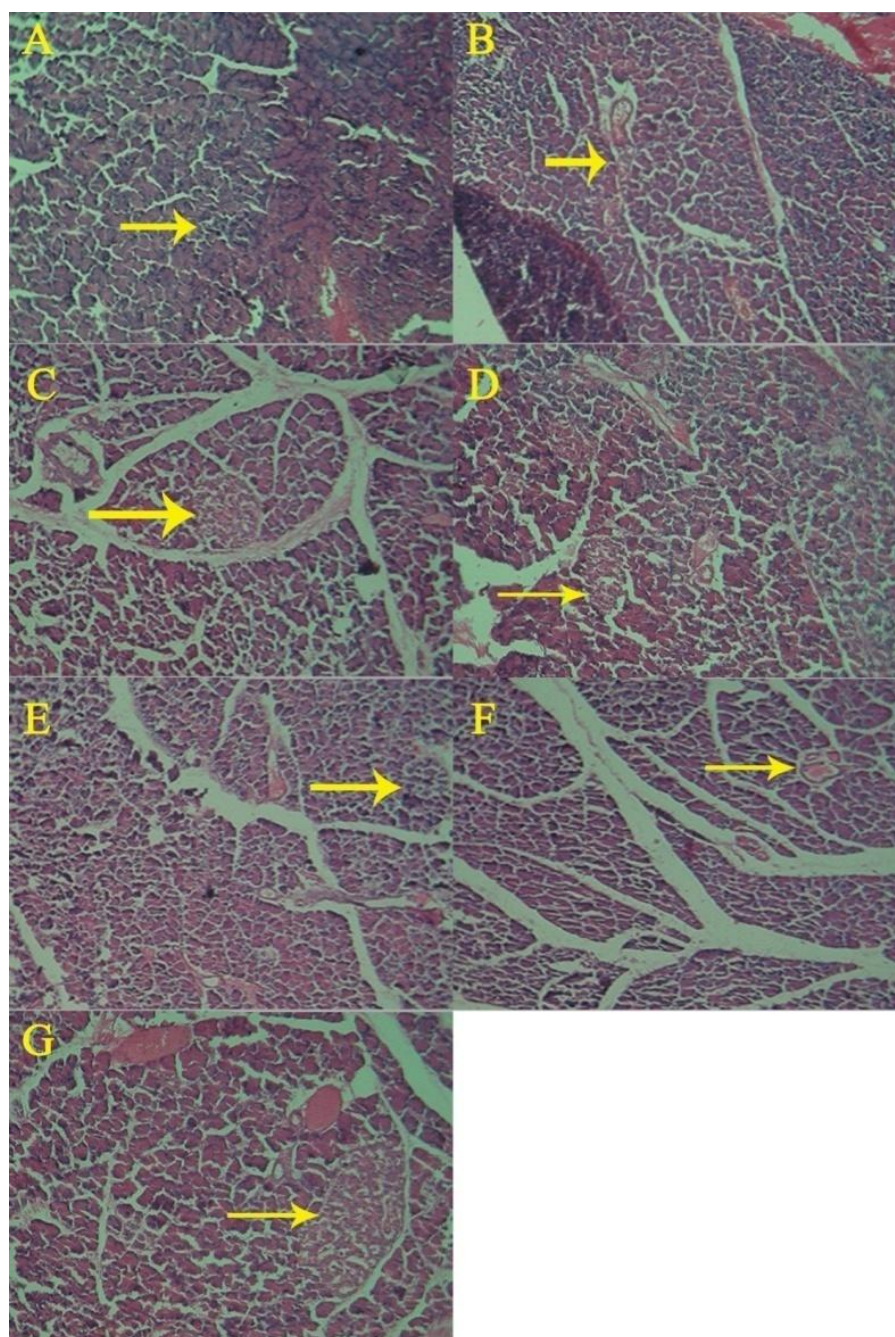

Fig. 2: Histological study of the pancreas (representative H\&E-stained): (A) Normal group, (B) Diabetic group, (C) Glibenclamide $5 \mathrm{mg} / \mathrm{kg}$, (D) ETM 250 $\mathrm{mg} / \mathrm{kg}$ treated, (E) ETM $500 \mathrm{mg} / \mathrm{kg}$ treated, (F) ETW $250 \mathrm{mg} / \mathrm{kg}$ treated and (G) ETW $500 \mathrm{mg} / \mathrm{kg}$

\section{DISCUSSION}

The principle underlying hyperglycaemia in DM involves decreased use of glucose by the tissues as well as over production of glucose via excessive hepatic glycogenolysis and gluconeogenesis (Latner, 1958). Persistent hyperglycaemia, the common feature of DM can result in complications. Thus, the purpose of the treatment was to control the elevated blood glucose level (Association, 1997).Traditionally Euphorbia species has been utilized in the management of DM (Alarcon-Aguilara, et al., 1998). In the present investigation, OGTT was supported that methanol and aqueous extracts of ET have the capability to reduce blood sugar levels. Hence, it is of interest to undertake a systematic study as their pharmacological activity like antidiabetic and antihyperlipidemic activity of extracts on STZ-NA induced DM in rats.

Antidiabetic studies reveal that aqueous and methanol extracts of ET have sub-chronic antidiabetic activity. The higher potential of ETM $(500 \mathrm{mg} / \mathrm{kg})$ over others extracts, which contains a polyphenol, triterpenoids, flavonoids and saponins that may result in increased antidiabetic potential (Verma, et al., 2013).

The DM in rats was manifested via intraperitoneal administration of STZ-NA. The vital foundation of DM occurs in rats was due to damage of $\beta$-cells of Langerhans (Shirwaikar, et al., 2006), which leads to the excessive breakdown of liver glycogen to glucose-6-phosphate along with a reduction in sugar consumption via tissue. The STZ oral administration alone might bring about hyperglycemia via fatal devastation of Langerhans of $\beta$-cells. Adjacent to this in a current experimental model combination of STZ-NA exhibit hyperglycaemia and reduce glucose resistance may cause DNA strand breaks which may lead to the progression of type-II diabetes (Lukić, et al., 1998). However, $\beta$-cells are still able to release insulin in the presence of sugar, which is likely to be same as to type II DM in human. The oral treatment with extracts exhibited a significant decrease in the elevated FBG levels and increase in serum insulin level. The mechanism behind the restoration in elevated FBG in diabetic rats was due to the enhancement of the activity of plasma insulin via either release from already existing $\beta$-cells or from its bound forms.

Excessive glucose present in the blood bound to the hemoglobin and increase significantly the percentage of $\mathrm{HbA} 1 \mathrm{c}$ in diabetic rats which may be due to the anabolic effect of insulin as well as the protein synthesis (Jarald, et al., 2013). Consequently, diabetic rats showed a significant increase in $\mathrm{HbA} 1 \mathrm{c}$ and decrease in hemoglobin levels in STZ-NA induced diabetic rats. The oral treatment with ET extracts showed a significant reduction in HbA1c level. The ability of methanol and water extracts of E. thymifolia to reduce HbA1c levels in diabetic rats showed its potential effect in prevention of the complication associated with diabetes mellitus. Urea is a chief molecule in the metabolism of protein. The deamination of amino acid in the liver produces ammonia which is converted to urea and excreted out through urinary system. However, some of urea is bound to hemoglobin and found higher in RBC than plasma (Ranjna, 1999). The significant $(\mathrm{P}<0.001)$ decrease in urea observed with diabetic rats treated with $E$. thymifolia ( $250 \mathrm{mg} / \mathrm{kg}$ and $500 \mathrm{mg} / \mathrm{kg}$ body weight) is clearly evident the potential effect of ET extracts which may not be due to the diminishing in urea cycle or decrease in glomerular filtration as in renal disease. Creatinine is waste product generated through muscle and protein diet. The higher concentration of creatinine in blood is clearly evident for the impairment of kidney functions. The present result reveals that, the treatment with extracts of ET aerial part have potential effect on STZ-NA induced increase in serum creatinine level. The earlier report stated that the liver glycogen levels has been decreased during DM (Grover, 
et al., 2000), this because of unavailability of insulin in DM which consequence into the inactivation of glycogen synthase (Huang, et al., 2000). The treatment with extracts of ET displayed a significant alteration in the hepatic glycogen level in rats as compared to the diabetic control group, which may be due to the induction of the glycogen synthase enzyme via enhancement of glycogenesis (Salahuddin and Jalalpure, 2010). Table 3 summarized the effect of STZ-NA on the activity of hepatic enzymes in serum which are served as marker in diabetes and obesity. In present investigation, liver enzymes such as SGPT, SGOT and ALP levels were increased significantly $(\mathrm{P}<0.005)$ in STZ-NA induced diabetic rats as compared to normal rats. This event was supported by evident that there is a leaking out of these enzymes from the liver cytosol and migrating into the circulation due to toxicity of STZ (Shokeen et al., 2008). The elevated enzyme levels were significantly restored to normal after treatment with ET extracts for 28 days support the antidiabetic effect. Furthermore, restoration in level of liver enzyme also indicates normal function of liver

The DM is showed significant changes in serum lipid profile may lead to hyperlipidaemia characterized by the elevation of TC, TG, and LDL levels. However, there was a decreased in levels of HDL (Verma, et al., 2012). In the meantime insulin has an inhibitory action on key enzyme 3-hydroxy-3-methyl-glutarylCoA reductase (HMG-CoA reductase), in de novo synthesis of cholesterol. Insulin resistance or deficiency results in activation of lipoprotein lipase, this consequence in hydrolyse TG which is associated with hyperlipidaemia in diabetic rats (Jarald, et al., 2008). In the present study, treatment with extracts of ET significantly reversed dyslipidaemia by the significant decrease in TC, TG and LDL coupled to increase in HDL. The mechanism behind antihyperlipidemic activities of plants would be a lesser generation of cholesterol, via decreasing the activity of HMG-CoA reductase enzyme (Sharma, et al., 2003). A histopathology study shows the partial destruction of the pancreatic cells in DM control animals as compared to normal control animals. The histopathology study of treated animals showed restoration of pancreatic cells near to normal in the extracts treated animals.

\section{CONCLUSION}

Euphorbia thymifolia control elevated blood glucose level in diabetic rats but also lower the lipid profile associated with this metabolic syndrome. The higher potential of ETM (500 $\mathrm{mg} / \mathrm{kg}$ ) over aqueous extracts, which contains a polyphenol, triterpenoids, flavonoids and saponins (Parmar and Pundarikakshudu, 2017) that may result in increased antidiabetic and antihyperlipidemic potential. This investigationis evidently corroborating the proclamations of the traditional system of medicine for Euphorbia thymifolia aerial parts as a regimen in the treatment of diabetes and obesity.

\section{ACKNOWLEDGEMENT}

We are grateful to Dr. A. K. Seth, HOD Department of
Pharmacy, Sumandeep Vidyapeeth, Piparia, Vadodara, Gujarat, India for providing the facilities during this study.

\section{Financial support and sponsorship: Nil.}

Conflict of Interests: There are no conflicts of interest.

\section{REFERENCE}

Akpan HB, Adefule AK, Fakoya FA and Caxton-Martins EA. Evaluation of LDH and G6-PDH activities in auditory relay centers of streptozocin-induced diabetic wistar rats. J. Anal. Sci, 2007; 1(1): 21-25.

Alarcon-Aguilara FJ, Roman-Ramos R, Perez-Gutierrez S, Aguilar-Contreras A, Contreras-Weber CC and Flores-Saenz JL. Study of the anti-hyperglycemic effect of plants used as antidiabetics. Journal of Ethnopharmacology, 1998; 61(2): 101-10.

Andersen L, Dinesen B, Jørgensen P, Poulsen F and Røder M. Enzyme immunoassay for intact human insulin in serum or plasma. Clinical Chemistry, 1993; 39(4): 578-82.

Association AD. Standards of medical care for patients with diabetes mellitus. Diabetes Care, 1997; 20(Supplement 1): S3-S13.

Bonner-Weir S. Morphological evidence for pancreatic polarity of $\beta$-cell within islets of Langerhans. Diabetes, 1988; 37(5): 616-21.

Carroll NV, Longley RW and Roe JH. The determination of glycogen in liver and muscle by use of anthrone reagent. Journal of Biological Chemistry, 1956; 220(2): 583-93.

Chandramohan G, Ignacimuthu S and Pugalendi KV. A novel compound from Casearia esculenta (Roxb.) root and its effect on carbohydrate metabolism in streptozotocin-diabetic rats. European journal of pharmacology, 2008; 590(1): 437-43.

Das T, Das B, Saha D and Mishra SB. Anti-Hyperglycemic Effect of Tecomella undulata Extract by Ameliorating Pancreatic Dysfunction in Streptozotocin Induced Diabetic Albino Rats. 2015;

Grover JK, Vats V and Rathi SS. Anti-hyperglycemic effect of Eugenia jambolana and Tinospora cordifolia in experimental diabetes and their effects on key metabolic enzymes involved in carbohydrate metabolism. Journal of Ethnopharmacology, 2000; 73(3): 461-70.

Huang X, Vaag A, Hansson M, Weng J, Laurila ESA and Groop L. Impaired Insulin-Stimulated Expression of the Glycogen Synthase Gene in Skeletal Muscle of Type 2 Diabetic Patients Is Acquired Rather Than Inherited 1. The Journal of Clinical Endocrinology \& Metabolism, 2000; 85(4): 1584-90.

Jarald E, Joshi S, Jain D and Edwin S. Biochemical evaluation of the hypoglycemic effects of extract and fraction of Cassia fistula linn. in alloxan-induced diabetic rats. Indian Journal of Pharmaceutical Sciences, 2013; 75(4): 427.

Jarald EE, Joshi SB and Jain DC. Antidiabetic activity of flower buds of Michelia champaca Linn. Indian Journal of Pharmacology 2008; 40(6): 256.

Kemper KJ and Lester MR. Alternative asthma therapies: An evidence-based review. Contemporary Pediatrics, 1999; 16(3): 162-95

King EJ and Armstrong AR. A convenient method for determining serum and bile phosphatase activity. Canadian Medical Association Journal, 1934; 31(4): 376

Latner A. Clinical Biochemistry. Philadelphia: Saunders.

Lee S-H, Tanaka T, Nonaka G-i and Nishioka I. Hydrolysable tannins from Euphorbia thymifolia. Phytochemistry, 1990; 29(11): 362125 .

Lowry OH, Rosebrough NJ, Farr AL and Randall RJ. Protein measurement with the Folin phenol reagent. J Biol Chem, 1951; 193(1): 265-75.

Lukić ML, Stošić-Grujičić S and Shahin A. Effector mechanisms in low-dose streptozotocin-induced diabetes. Clinical and Developmental Immunology, 1998; 6(1-2): 119-28.

Masiello P, Broca C, Gross R, Roye M, Manteghetti M, Hillaire-Buys D, Novelli $M$ and Ribes G. Experimental NIDDM: 
development of a new model in adult rats administered streptozotocin and nicotinamide. Diabetes, 1998; 47(2): 224-9.

Mwine TJ and Van Damme P. Why do Euphorbiaceae tick as medicinal plants?: a review of Euphorbiaceae family and its medicinal features. Journal of Medicinal Plants Research, 2011; 5(5): 652-62.

OECD. Guidline no. 423 for testing of chemical revised draft guidline 423 (acute oral toxicity). Paris:

Ohkawa H, Ohishi N and Yagi K. Assay for lipid peroxides in animal tissues by thiobarbituric acid reaction. Analytical biochemistry, 1979; 95(2): 351-58

Owen J, Iggo B, Scandrett F and Stewart C. The determination of creatinine in plasma or serum, and in urine; a critical examination. Biochemical Journal, 1954; 58(3): 426.

Palsamy $\mathrm{P}$ and Subramanian S. Resveratrol, a natural phytoalexin, normalizes hyperglycemia in streptozotocin-nicotinamide induced experimental diabetic rats. Biomedicine \& Pharmacotherapy, 2008; 62(9): 598-605.

Parmar G and Pundarikakshudu K. Comparative Pharmacognostic and Phytochemical Standardization of Euphorbia hirta L. and Euphorbia thymifolia L. American Journal of Pharmtech Research, 2017; 7(1): 531-44.

Ranjna C. Practical clinical biochemistry methods and interpretation. Jaypee Brothers Medical Publishers, India, 1999;

Reitman S and Frankel S. A colorimetric method for the determination of serum glutamic oxalacetic and glutamic pyruvic transaminases. American journal of clinical pathology, 1957; 28(1): 56-63.

Salahuddin MD and Jalalpure SS. Antidiabetic activity of aqueous fruit extract of Cucumis trigonus Roxb. in streptozotocininduced-diabetic rats. Journal of ethnopharmacology, 2010; 127(2): $565-$ 67.

Sharma SB, Nasir A, Prabhu KM, Murthy PS and Dev G. Hypoglycaemic and hypolipidemic effect of ethanolic extract of seeds of Eugenia jambolana in alloxan-induced diabetic rabbits. Journal of Ethnopharmacology, 2003; 85(2): 201-06.
Shirwaikar A, Rajendran K and Barik R. Effect of aqueous bark extract of Garuga pinnata Roxb. in streptozotocin-nicotinamide induced type-II diabetes mellitus. Journal of Ethnopharmacology, 2006; 107(2): 285-90.

Shokeen P, Anand P, Murali YK and Tandon V. Antidiabetic activity of $50 \%$ ethanolic extract of Ricinus communis and its purified fractions. Food Chem Toxicol, 2008; 46(11): 3458-66.

Taylor SI, Accili D and Imai Y. Insulin resistance or insulin deficiency: which is the primary cause of NIDDM? Diabetes, 1994; 43(6): 735-40.

Varley H. Practical clinical biochemistry. Practical clinical biochemistry., 1954;

Verma N, Amresh G, Sahu PK, Mishra N, Singh AP and Rao CV. Antihyperglycemic activity, antihyperlipedemic activity, haematological effects and histopathological analysis of Sapindus mukorossi Gaerten fruits in streptozotocin induced diabetic rats. Asian Pacific Journal of Tropical Medicine, 2012; 5(7): 518-22.

Verma PR, Itankar PR and Arora SK. Evaluation of antidiabetic antihyperlipidemic and pancreatic regeneration, potential of aerial parts of Clitoria ternatea. Revista Brasileira de Farmacognosia, 2013; 23(5): 819. 29.

\section{How to cite this article:}

Parmar GR, Pundarikakshudu K, Balaraman R. Antidiabetic and antihyperlipidemic activity of Euphorbia thymifolia L. extracts on streptozotocin-nicotinamide induced type 2 diabetic rats. J App Pharm Sci, 2017; 7 (08): 078-084. 